\title{
Anna Kwiecień*
}

\section{EFEKTYWNOŚĆ RELACJI W SIECI}

\section{WPROWADZENIE}

Faktem stała się sytuacja, w której organizacje, aby sprostać rosnącym wyzwaniom rynku tworzą sieci relacji, transakcji i kapitałów, charakteryzujące się coraz większą elastycznością. Zbudowany w ten sposób synergiczny potencjał umożliwia partnerom realizacje celów, niemożliwych do osiagnięcia indywidualnie. Główny cel wielu przedsiębiorstw nadal definiowany jest jako dążenie do wzrostu wartości, jednak uwarunkowania rynku wymuszają specyficzny sposób postępowania, konieczny dla jego osiagnięcia, oparty na wykorzystaniu wzajemnych relacji.

Specyfika współczesnego rynku powoduje, że samodzielna realizacja wszystkich funkcji wewnątrz przedsiębiorstwa jest praktycznie niemożliwa, zaś budowanie relacji bezpośrednich między zainteresowanymi pozwala na osiągnięcie efektu synergii i tym samym wzmocnienie siły procesów generujących wartość.

W świetle takich założeń celem niniejszego opracowania jest prezentacja relacji i ich efektów, jako źródeł wartości współczesnych przedsiębiorstw działających w sieci różnorodnych powiązań.

\section{EFEKTY RELACJI W SIECI}

Współczesny rynek charakteryzuje się tym, że skupia się i opiera swoje działania na tworzeniu relacji. Każda organizacja jest swoistego rodzaju siecią relacji występujących pomiędzy zasobami będącymi w jej posiadaniu lub dyspozycji. Centralnymi elementami tej sieci są ludzie, których spajają różnego rodzaju zależności. Jednak można także zaobserwować relacje występujące między

\footnotetext{
* Dr, Uniwersytet Ekonomiczny w Katowicach.
} 
ludźmi i pozostałymi zasobami organizacji, jak i tylko między zasobami organizacji, z wyłączeniem ludzi ${ }^{1}$. Oprócz tego typu relacji wewnętrznych określających daną organizację, ogromną rolę na współczesnych rynkach odgrywają relacje międzyorganizacyjne.

Pod pojęciem relacji międzyorganizacyjnych należy rozumieć takie powiązania między przedsiębiorstwami, w ramach których zakłada się uzyskanie przez strony relacji wzajemnych korzyści, dzięki długookresowej orientacji kooperantów, zaangażowaniu przez nich określonych zasobów oraz wysokiej skłonności stron relacji do podejmowania działań adaptacyjnych na rzecz współpracy².

Funkcjonowanie sieci organizacyjnych umożliwia łączenie sił $\mathrm{w}$ ramach wspólnych inicjatyw i aktywności innowacyjnej, wykorzystanie różnych unikalnych umiejętności, jak i tworzenie specjalistycznych konfiguracji kompetencji rozmieszczonych w wielu organizacjach uczestniczących w sieci.

Należy w tym miejscu zwrócić uwagę na pojęcie kompetencji relacyjnej, która towarzyszy istnieniu sieci. Same relacje nie gwarantują wzrostu wartości przedsiębiorstw działających w sieci, konieczne do tego są kompetencje, dzięki którym te relacje mogą zostać utworzone.

Pojęcie to nawiązuje do pojęcia kluczowych kompetencji ${ }^{3}$. Następstwem posiadania odpowiednich kompetencji jest powstanie na rynku stosownych relacji - mówimy wówczas o kompetencji relacyjnej.

Kompetencja relacyjna jest kombinacją wielu umiejętności i skłonności polegania na zaufaniu, która w warunkach zmiennego otoczenia prowadzi do sukcesu współdziałania przedsiębiorstw ${ }^{5}$.

Mobilizacja nawzajem aktywności organizacji w ramach sieci odnosi się zarówno do działań i procesów wykorzystania unikalnych dostępnych zasobów partnerów, jak i podnoszenia efektywności łańcuchów poprzez włączenie do nich innych partnerów sieciowych w ramach wspólnych inicjatyw.

Współpraca organizacji w ramach sieci partnerskich umożliwia ich uczestnikom dotarcie i efektywnie wykorzystanie lepiej wykształconych, wyspecjali-

${ }^{1}$ B. Mikuła, Relacje jako element kapitału ludzkiego, [w:] J. S. K a rd a s (red.), Budowanie relacji w zarzadzaniu zasobami ludzkimi, Wydawnictwo Studio Emka, Warszawa 2009, s. 95.

${ }^{2} \mathrm{~A}$. S u dols ka, Uwarunkowania budowania relacji proinnowacyjnych przez przedsiębiorstwa w Polsce, Wydawnictwo Naukowe UMK, Toruń 2011, s. 32.

${ }^{3}$ Zob. także: C. K. Prahald, G. Hame1, The Core Competence of the Corporation, „Harvard Business Review”, May-June 1990, [za:] M. J. S tanki e wi cz, Konkurencyjność przedsiębiorstwa, TNOiK, Stowarzyszenie Wyższej Użyteczności „Dom Organizatora”, Toruń 2002, s. 211.

${ }^{4}$ Oprócz kompetencji relacyjnej skierowanej do konkretnego partnera istnieje także ogólna kompetencja relacyjna, użyteczna przy tworzeniu wartości w wielu więziach międzyorganizacyjnych i określa się ją mianem kompetencji współdziałania. Pojawia się również pojęcie kompetencji sieciowej, która dotyczy całej struktury relacji.

${ }^{5}$ A. Arino, J. de la Torre, P. S. Ring, Relational Quality: Managing Trust in Corporate Aliances, „California Management Review” 2001, vol. 44, no. 1, s. 109-131, [za:] W. Czako n, Dynamika więzi międzyorganizacyjnych, Wydawnictwo AE w Katowicach, Katowice 2007, s. 231. 
zowanych, utalentowanych i wykwalifikowanych ludzi, pozwala dotrzeć do wyższych unikalnych umiejętności pozwalających na przyspieszoną budowę wyjątkowego kluczowego potencjału decydującego o sukcesie w realizacji przedsięwzięć prowadzących do osiagania przyjętego celu, dla którego stworzono sieć. Szczególne efekty z wejścia w relację sieciową mogą być następujące:

- dotarcie do szerszego wachlarza wyspecjalizowanych organizacji i ich kluczowych procesów oraz najlepszych praktyk,

- efektywne korzystanie z szybko rozwijających, rozszerzających się źródeł i możliwości zmobilizowania zasobów zlokalizowanych poza organizacją,

- współpraca z tymi, którzy zapewniają naprawdę istotną, unikalną wartość,

- dostęp do nowej wiedzy poprzez rozwinięcie procesów uczenia się od innych partnerów oraz zdobywanie lepszych umiejętności wspólnego rozwiązywania trudnych problemów społecznych, biznesowych między innymi dzięki lepszemu rozumieniu stojących przed organizacjami wyzwań i możliwości,

- skuteczne łączenie wysiłków w budowaniu potencjału sieci dzięki skupieniu twórczych ludzi o odpowiednich kwalifikacjach o umiejętnościach kreatywnego działania w zakresie wyznaczania celów, zadań i sposobów ich rozwiązywania,

- dostęp do nowych źródeł informacji, rozszerzonej bazy danych i systemów informacyjnych zapewniających przepływ informacji zarówno wewnątrz sieci organizacyjnej, jak i zewnątrz do sieci oraz współuczestnictwo wszystkich partnerów w wykorzystywaniu sieciowego systemu informacyjnego (wykorzystanie obiektywnego, zintegrowanego modelu dynamicznego identyfikującego najistotniejsze funkcje i procesy występujące w sieci) ${ }^{6}$.

Jako efekty nawiązania relacji i tworzenia struktur sieciowych wymienia się również:

- zmniejszenie niepewności,

- zwiększenie stopnia elastyczności,

- zapewnienie odpowiedniego potencjału,

- zapewnienie większej szybkości działania, w celu wykorzystania nadarzających się szans i okazji rynkowych,

- zwiększenie dostępu do zasobów i informacji ${ }^{7}$.

Konstatacją rozważań nad efektami relacji może być stwierdzenie J. Niemczyka $^{8}$, który istotę strategii sieci dostrzega w kształtowaniu innowacyjnych

${ }^{6}$ W. Chmi elarz, Zagadnienia analizy i projektowania informatycznych systemów wspomagajacych zarzqdzanie, Wydawnictwo Naukowe Wydziału Zarządzania Uniwersytetu Warszawskiego, Warszawa 2000, s. 21.

${ }^{7}$ J. Child, D. Faulkner, S. Tallman, Cooperative Strategy. Managing Alliances, Networks and Joint Ventures, Oxford University Press, Oxford 2005, s. 147 i nast.

${ }^{8} \mathrm{~J}$. N i e m c z y k, Wyróżniki, budowa i zachowania strategiczne układów outsourcingowych, AE, Wrocław 2006. 
układów współpracy, dzięki którym możliwe staje się przejmowanie wartości dodanej z tytułu uczestnictwa w takich układach (sieciach) współpracy. Chęć pozyskania szeroko rozumianej wartości dodanej, pochodzącej z różnych źródeł, wyraża ogólną intencję tworzenia relacji.

Analiza wielu sytuacji rynkowych pozwala na stwierdzenie, że uwzględnienie korzyści wielu podmiotów, z którymi nawiązujemy relacje (interesariuszy) i budowa wszelkich związków lojalnościowych z otoczeniem przysparza wartości firmie, a co więcej, bez wzajemnej współpracy nie jest możliwy długofalowy wzrost. Zrównoważony rozwój wymaga więc inwestowania w partnerskie stosunki z otoczeniem ${ }^{9}$.

Tak jak różne mogą być intencje tworzenia sieci relacji, tak różne mogą być cząstkowe efekty z nich uzyskiwane, jednak wszystkie one powinny mieć wartościotwórczy charakter. Jednym z wyznaczników tworzenia relacji może być stwierdzenie, że współczesna gospodarka wymaga nastawienia kooperacyjnego, które należy rozumieć jako wspólne, zespołowe działanie, u podstaw którego leży możliwość znacznego obniżenia kosztów i zwiększenia efektywności działania ${ }^{10}$. Można również powiedzieć, że efektem wynikającym $\mathrm{z}$ nawiązywania relacji jest osiaggnięcie wzrostu rentowności działania. Jest to możliwe dzięki temu, że przez współpracę firmy mogą aktywnie ograniczać koszty działalności, dzielić ryzyko, pozyskiwać wyjątkową wiedzę, uzyskać dostęp do rynków zbytu oraz transferu technologii ${ }^{11}$.

Sieci stają się rozwiązaniami minimalizującymi koszty transakcyjne, które obniżone zostają do poziomu, jaki dawała hierarchia, ale bez kosztów hierarchii, dlatego właśnie sieć stała się logicznie efektywnym rozwiązaniem ${ }^{12}$.

Kolejnym efektem relacji w sieci wartości może być tworzenie i dyfuzja wiedzy. Sieć stwarza bowiem warunki do samoczynnego poszerzania przestrzeni wartości. Zdaniem K. Perechudy, główną wartością sieci jest zdolność do kreowania wiedzy niejawnej firmy - integratora, a następie dyfuzja wiedzy do kooperantów ${ }^{13}$.

Specyficzne, z punktu widzenia efektów relacji, jest także pojęcie efektu sieciowego. Jest to efekt przejawiający się we wzroście użyteczności, jaką odczuje konsument z tytułu przyłączenia do sieci kolejnego jej użytkownika. To może oznaczać, że w pewnych przypadkach, atrakcyjność sieci wzrośnie wraz ze zwiększeniem się liczby jej uczestników, a to może wpływać na wzrost war-

${ }^{9}$ B. Domańska-S zaruga, Kapitat relacji jako źródło wartości przedsiębiorstwa, [w:] B. Domańska-Szaruga (red.), Budowanie relacji z klientami, Wydawnictwo Studio Emka, Warszawa 2009, s. 13.

${ }^{10} \mathrm{D}$. Nowak, Zarzqdzanie międzyorganizacyjnymi relacjami kooperacyjnymi $w$ przedsiębiorstwach przemystowych, Wydawnictwo UE w Poznaniu, Poznań 2012, s. 5.

${ }^{11}$ M. B en g t s s o n, S. Ko ck, Competition in Business Networks - to Cooperate and Compete Simultaneously, ,Industrial Marketing Management” 2000, vol. 14, no. 3, s. 411-426.

${ }_{12}$ J. N i e m c zy k, Skąd się wzięty sieci?, „Studia Ekonomiczne Regionu Łódzkiego. Formy i uwarunkowania współpracy we współczesnej gospodarce” 2012 (wydanie specjalne), s. 18.

${ }^{13}$ K. Pe re chu d a, Dyfuzja wiedzy, Wydawnictwo AE we Wrocławiu, Wrocław 2005, s. 118. 
tości firm w takiej sieci uczestniczących ${ }^{14}$. Czyli w tym przypadku efekt relacji jest korzystny zarówno dla uczestników sieci, jak i jej klientów.

Relacje same w sobie stanowią cenny zasób, ponadto można je analizować z perspektywy renty ekonomicznej ${ }^{15}$, której uzyskanie może być postrzegane jako istota w kontekście efektów nawiązywania relacji i generowania wartości dodanej.

Renta może być ogólnie definiowana jako zysk przedsiębiorcy ponad koszt zaangażowanego kapitału. Źródła tego zysku są różnorodne. Wśród typowych źródeł renty ekonomicznej w sieci należą:

- nadwyżka z tytułu niższych kosztów transakcyjnych i niższych kosztów hierarchii,

- nadwyżka z tytułu tworzenia wartości w logice łańcucha, warsztatu lub sieci wartości,

- nadwyżka z tytułu apriopriacji wartości powstającej u innych uczestników sieci, jawnej,

- nadwyżka z tytułu sieciowego tworzenia i dysfazji w sieci wiedzy nie- efekt sieciowy.

Każda z tych nadwyżek stanowi specyficzny efekt relacji w sieci wartości.

\section{ZDOLNOŚĆ SIECIOWA A EFEKTYWNOŚĆ RELACJI}

Zdolność sieciowa - relacyjna, to zdolność obejmująca rozwiązania, procedury i kompetencje odnoszące się do wymiaru wewnętrznego i zewnętrznego, a także zdolność do inicjowania, utrzymywania i wykorzystywania relacji z różnymi partnerami zewnętrznymi ${ }^{16}$. Zdolność sieciowa oznacza także zdolność przedsiębiorstwa do uczestniczenia w relacjach partnerskich ${ }^{17}$. Inaczej, zdolność

${ }^{14}$ J. Ni e m c zy k, Strategia. Od planu do sieci, Wydawnictwo UE we Wrocławiu, Wrocław 2013, s. 37.

${ }^{15}$ Renta ekonomiczna w tym wypadku określana mianem renty relacyjnej, jest to renta, która powstaje dzięki współdziałaniu uczestników sieci i nawiązuje do zjawiska synergii. Renta ta czerpana jest z relacji międzyorganizacyjnych, które, jak już wyjaśniono, są składnikiem zasobów sieciowych. Powstaje ona w przypadku zaistnienia wymiany materialnych i niematerialnych zasobów pomiędzy uczestnikami sieci oraz w przypadku ich inwestycji w zasoby międzyorganizacyjne. To właśnie dzięki takim działaniom obniżają się koszty transakcyjne a potencjał synergii wzrasta. Zob. J. Ni e m c z y k, E. S t ań c z y k - Hu g i e t, B. J a s iń s ki (red.), Sieci międzyorganizacyjne. Wspótczesne wyzwanie dla teorii i praktyki zarzqdzania, Wydawnictwo C. H. Beck, Warszawa 2012, s. 352.

${ }^{16}$ Por. A. Wój cik-Karpacz, Zdolność relacyjna $w$ tworzeniu efektów wspótdziatania matych i średnich przedsiębiorstw, Oficyna Wydawnicza SGH w Warszawie, Warszawa 2012, s. 38 i nast.

${ }^{17}$ J. H. Dyer, H. Singh, The Relational View: Cooperative Strategy and Sources of Interorganization Competitive Advantage, „Academy of Management Review” 1998, vol. 23, no. 4 , s. 672 . 
sieciowa może być ujmowana jako celowo wykreowana kombinacja struktur zarządzania i koordynacji, co umożliwia tworzenie wartości pod warunkiem istnienia wspólnych zasobów ${ }^{18}$.

Pojęcie zdolności relacyjnej jest złożone i niejednorodne, tak jak cała kategoria relacji i powiązań relacyjnych. Jednak analizując wielość podejść do tego zagadnienia, można wskazać na jego trzy główne cechy:

- kładzie duży nacisk na doświadczenie i procesy uczenia się przez przedsiębiorstwo, które może nabyć i rozwinąć wiedzę o zarządzaniu zestawem relacji,

- proces wymiany wiedzy zapoczątkowuje budowę specyficznego mechanizmu wewnątrzorganizacyjnego dotyczącego zarządzania relacjami zewnętrznymi,

- podkreśla dążenie do zintegrowanego zarządzania szerszym zestawem relacji z partnerami zewnętrznymi, realizowanym przy uwzględnieniu wspólnych interesów stron relacji ${ }^{19}$.

W tym kontekście, specyfikę sieci przedstawić można jako wielopodmiotowy układ (relację) decydentów, którzy nie podejmują decyzji w izolacji, ale ze względu na oczekiwane zachowania innych uczestników oraz oczekiwane efek$t^{20}$. Osiaganie wspólnych celów przez organizację w sieci powinno być postrzegane w kategoriach efektywności. To oznacza, że więzi międzyorganizacyjne są dopuszczalne, gdy każdy ich uczestnik osiaga efekty nie mniejsze niż nakłady poniesione na ich uzyskanie ${ }^{21}$. Sieć powinna więc tworzyć sytuacje korzystne dla wszystkich jej uczestników.

Aby mieć świadomość efektywności zdolności relacyjnej, warto zwrócić uwagę na jej podstawowe komponenty, aby, wykorzystując proces uczenia się, móc je rozwijać. Komponentami tymi są:

- działania (funkcje) - związane z realizacją zadań wynikających z relacji zewnętrznych,

- narzędzia - wspomagające zarządzanie relacjami z partnerami rynkowymi,

- procedury zarządzania i kontroli - nastawione na wspieranie konkretnych aspektów współdziałania z partnerami rynkowymi,

- zaangażowanie podmiotów zewnętrznych - konsultantów - dostarczając zasobów wiedzy potrzebnych do zarządzania relacjami z partnerami rynkowymi ${ }^{22}$.

${ }^{18}$ W. C z a k o n, Relational Capabilities of Organizations: Theoretical Advances, ,Journal of Economics and Management” 2009, vol. 5, UE w Katowicach, Katowice, s. 58.

${ }^{19}$ A. Wó j ci k-Karpa c z, op. cit., s. 40 i nast.

${ }^{20}$ W. C z a ko n, Dynamika więzi..., op. cit., s. 118.

${ }^{21}$ S. H. Park, D. Zho n, Firm Heterogeneity and Competitive Dynamics in Alliance Formation, „The Academy of Management Review” 2005, vol. 30, no. 3, s. 531 i nast.

${ }^{22} \mathrm{~A}$. P a g a $\mathrm{o}$, The role of relational capabilities in the organization of international sourcing activities, „Industrial Marketing Management” 2009, vol. 38, no. 8, s. 903 i nast. 
Analiza poszczególnych wymiarów zdolności relacyjnej prowadzi do lepszego jej rozumienia. Konieczne jest jednak uświadomienia sobie dodatkowych uwarunkowań kreowania relacji na współczesnym rynku.

Coraz częściej można też spotkać stwierdzenie, że osiagnięcie sukcesu (efektywności), zwłaszcza w warunkach bardzo silnej konkurencji, jest możliwe dopiero przy wykorzystaniu potencjału innych przedsiębiorstw $w$ ramach realizowanej współpracy ${ }^{23}$. Wynika z tego, że posiadanie zdolności sieciowej jest w dzisiejszych czasach warunkiem koniecznym dla efektywnego działania na rynku i kreowania wartości. Tego typu wniosek można wysunąć analizując definicję źródeł przewagi konkurencyjnej opartą na podejściu zasobowym (RBV - resource based view), które wskazuje, że różnice w efektach osiaganych przez przedsiębiorstwa wynikają z posiadanych przez nie zasobów ${ }^{24}$. Zasoby warunkują możliwość wejścia w określoną relację, a następnie możliwość opracowania i wdrożenia konkretnej strategii. Zasoby ${ }^{25}$ są więc czynnikiem determinującym zdolność relacyjną poszczególnych podmiotów na rynku i jej efektywność. Są czynnikiem istotnym dla nawiązania relacji i czerpania z nich korzyści, ale nie jedynym.

Aby współpraca międzyorganizacyjna była wzajemnie możliwa i korzystna, powinny być spełnione następujące warunki:

- występowanie komplementarności strategicznej między stronami,

- trwałe osłabienie siły rynkowej podmiotów w porównaniu z liderami rynku,

- przeświadczenie o możliwości zwiększenia kompetencji i jednoczesnej ochrony własnych umiejętności ${ }^{26}$.

Podstawą do podejmowania racjonalnych decyzji relacyjnych mogą być także występujące koszty transakcyjne, które muszą zostać poniesione w związ$\mathrm{ku} \mathrm{z}$ przeprowadzaniem transakcji hierarchicznie (wewnątrz organizacji) lub pomiędzy przedsiębiorstwami na rynku (należy pamiętać, że nie można ich traktować jako jedynego uzasadnienia podejmowanych decyzji).

Koszty wpływają na ekonomiczną efektywność transakcji i warunkują powstawanie i rozwój przedsiębiorstw sieciowych. Zarządzając relacjami trzeba dokonać pewnego rachunku opłacalności, w którym rozważa się opłacalność danej relacji, a w przypadku dostrzeżenia braku jej efektywności, zastąpienie jej

${ }^{23}$ W. Gla bis ze w ski, A. S u dolsk a, Rola wspótpracy $w$ procesie ksztattowania konkurencyjności przedsiębiorstwa, „Organizacja i Kierowanie” 2009, nr 2(136), s. 9.

${ }^{24} \mathrm{~B}$. Wernefelt, A resource-based view of the firm, „Strategic Management Journal” 1984 , vol. 5 , no. 2 , s. 171 i nast.

${ }^{25}$ Zasoby obejmują ogół aktywów, zdolności, procesów organizacyjnych, atrybutów przedsiębiorstwa, informacji, wiedzy, kontrolowanych przez przedsiębiorstwo i umożliwiających tworzenie oraz implementację skutecznej i efektywnej strategii. Zob. J. B. B arn ey, Firm resources and sustained competitive advantage, ,Journal of Management” 1991, vol. 17, no. 1, s. 101.

${ }^{26}$ M. S k a kib a r a, Formation of R\&D Consortia: Industry and Company Effects, ,,Strategic Management Journal" 2002, vol. 23, no. 11, s. 143. 
relacją $\mathrm{z}$ innym podmiotem, który będzie wykonywał lepiej powierzone mu funkcje.

Koszty transakcyjne mogą więc stanowić, obok samej zdolności sieciowej, istotny czynnik warunkujący efektywność relacji.

\section{PODSUMOWANIE}

Podsumowując, można stwierdzić, że wartościotwórcze efekty relacji mają bardzo różny charakter i mogą być rozpatrywane na różnych płaszczyznach. Można rozpatrywać je w wielu wymiarach, które wynikają $\mathrm{z}$ różnych intencji nawiązywania relacji, jednak można dokonać pewnego uogólnienia i wyrazić ją w dwóch wymiarach: jako korzyści pieniężne i niepieniężne dla firmy. Relacje z punktu widzenia korzyści pieniężnych obejmują wszelkiego rodzaju przepływy finansowe i zasobowe dokonywane przez nabywców oraz koszty związane z ich obsługą. Postrzeganie relacji przez pryzmat niepieniężnych korzyści pozwala na uwzględnienie przepływu wiedzy i informacji.

Podstawą efektywnych relacji jest zdolność sieciowa, czyli zdolność przedsiębiorstwa do uczestniczenia w relacjach partnerskich.

Jest to zdolność do inicjowania, utrzymywania i wykorzystywania relacji z różnymi partnerami zewnętrznymi, obejmująca także rozwiązania, procedury i kompetencje odnoszące się do wymiaru wewnętrznego.

Posiadanie zdolności sieciowej można potraktować jako warunek konieczny dla efektywnego działania na rynku i kreowania wartości.

\section{BIBLIOGRAFIA}

Arino A., de la Torre J., Ring P. S., Relational Quality: Managing Trust in Corporate Aliances, „California Management Review” 2001, vol. 44, no 1.

B arne y J. B., Firm resources and sustained competitive advantage, „Journal of Management” 1991, vol. 17 , no. 1 .

Bengtsson M., Kock S., Competition in Business Networks - to Cooperate and Compete Simultaneously, ,Industrial Marketing Management” 2000, vol. 14, no. 3.

Child J., Faulkner D., Tallman S., Cooperative Strategy. Managing Alliances, Networks and Joint Ventures, Oxford University Press, Oxford 2005.

$\mathrm{Ch}$ mi elar z W., Zagadnienia analizy i projektowania informatycznych systemów wspomagajacych zarzadzanie, Wydawnictwo Naukowe Wydziału Zarządzania Uniwersytetu Warszawskiego, Warszawa 2000.

Czakon W., Dynamika więzi międzyorganizacyjnych, Wydawnictwo AE Katowice, Katowice 2007.

Czakon W., Relational Capabilities of Organizations: Theoretical Advances, ,Journal of Economics and Management" 2009, vol. 5, UE w Katowicach, Katowice. 
Do mań ska-S z aru ga B., Kapitat relacji jako źródto wartości przedsiębiorstwa, [w:] B. Domańs k a-S zaruga, Budowanie relacji z klientami, Wydawnictwo Studio Emka, Warszawa 2009.

Dyer J. H., Singh H., The Relational View: Cooperative Strategy and Sources of Interorganization Competitive Advantage, „Academy of Management Review” 1998, vol. 23 , no. 4.

Glabis zew ski W., S udolsk a A., Rola wspótpracy w procesie kształtowania konkurencyjności przedsiębiorstwa, „Organizacja i Kierowanie” 2009, nr 2(136).

Mikuła B., Relacje jako element kapitału ludzkiego, [w:] J. S. Kardas (red.), Budowanie relacji w zarzqdzaniu zasobami ludzkimi, Wydawnictwo Studio Emka, Warszawa 2009.

N i e m c z y k J., Skq̨d się wzięty sieci?, „Studia Ekonomiczne Regionu Łódzkiego. Formy i uwarunkowania współpracy we współczesnej gospodarce” 2012 (wydanie specjalne).

Niemczyk J., Stańczyk-Hugiet E., Jasiński B. (red.), Sieci międzyorganizacyjne. Wspótczesne wyzwanie dla teorii i praktyki zarzqdzania, Wydawnictwo C. H. Beck, Warszawa 2012.

Ni e m c zy k J., Strategia. Od planu do sieci, Wydawnictwo UE we Wrocławiu, Wrocław 2013.

Ni e mczyk J., Wyróżniki, budowa i zachowania strategiczne układów outsourcingowych, AE, Wrocław 2006.

Nowak D., Zarzadzanie międzyorganizacyjnymi relacjami kooperacyjnymi $w$ przedsiębiorstwach przemystowych, Wydawnictwo UE w Poznaniu, Poznań 2012.

$\mathrm{Pag}$ ano A., The role of relational capabilities in the organization of international sourcing activities, ,Industrial Marketing Management” 2009, vol. 38, no. 8.

Park S. H., Zhon D., Firm Heterogeneity and Competitive Dynamics in Alliance Formation, „The Academy of Management Review” 2005, vol. 30, no. 3.

Pere chud a K., Dyfuzja wiedzy, Wydawnictwo AE we Wrocławiu, Wrocław 2005.

Prahald C. K., Hame G., The Core Competence of the Corporation, „Harvard Business Review", May-June 1990.

$\mathrm{S}$ k a kib a r a M., Formation of R\&D Consortia: Industry and Company Effects, „Strategic Management Journal" 2002, vol. 23, no. 11.

Stankiewicz M. J., Konkurencyjność przedsiębiorstwa, TNOiK, Stowarzyszenie Wyższej Użyteczności „Dom Organizatora”, Torun 2002.

Sudolska A., Uwarunkowania budowania relacji proinnowacyjnych przez przedsiębiorstwa w Polsce, Wydawnictwo Naukowe UMK, Torun 2011.

W e r n e fe lt B., A resource-based view of the firm, „Strategic Management Journal” 1984, vol. 5, no. 2.

Wój ci k-Karpac z A., Zdolność relacyjna $w$ tworzeniu efektów współdziatania małych $i$ średnich przedsiębiorstw, Oficyna Wydawnicza SGH w Warszawie, Warszawa 2012.

\section{Anna Kwiecień}

\section{EFFECTIVENESS NETWORK VALUE RELATIONS}

It can be concluded that the value-creating effect relationships are very different in nature and can be dealt with at different levels. You can deal with them in a number of dimensions, which result from the different intentions of establishing a relationship, but you can make some generalizations and express it in two dimensions, as monetary and non-monetary benefits for the company. Reports from the point of view of monetary benefits include all kinds of financial flows and resource made by the buyers, and the costs associated with their service. The perception of the 
relationship from the perspective of non-cash benefits allows for the flow of knowledge and information.

The basis of effective relationships is the ability of a network or the ability of the company to participate in partner relationships. It is the ability to initiate, maintain and use relationships with various external partners, including the arrangements, procedures and powers relating to the internal dimension.

Having a network capacity can be regarded as a prerequisite for the effective operation of the market and create value.

Key words: relationships, efficiency, value, network ability. 